
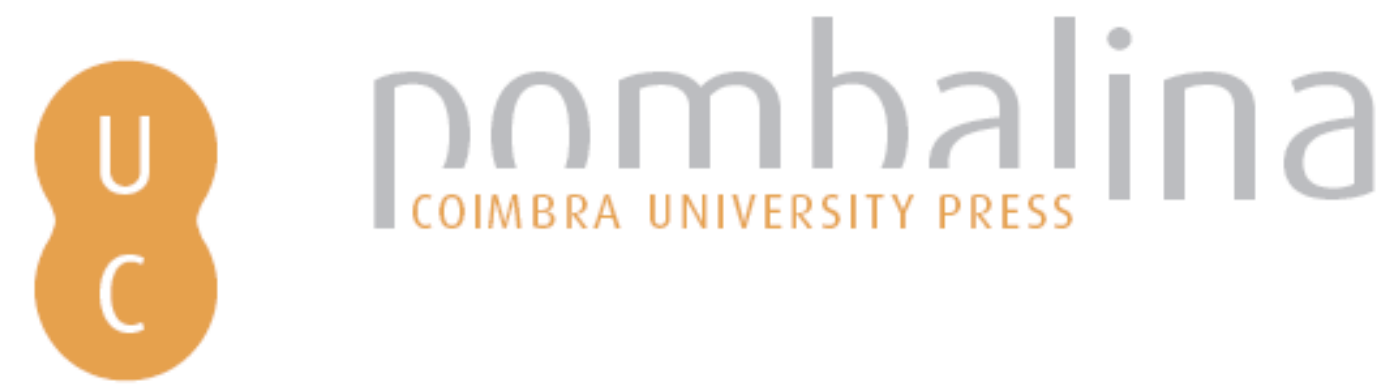

Organismos genéticamente modificados: a necessidade da correta delimitação e
divulgação do espaço destinado ao plantio como mecanismo de proteção ambiental

Autor(es): $\quad$ Nogueira, Luana P.

Publicado por: Imprensa da Universidade de Coimbra

URL

persistente: URI:http://hdl.handle.net/10316.2/37062

DOI: $\quad$ DOI:http://dx.doi.org/10.14195/978-989-26-0983-6_9

Accessed : $\quad$ 26-Apr-2023 10:36:41

A navegação consulta e descarregamento dos títulos inseridos nas Bibliotecas Digitais UC Digitalis, UC Pombalina e UC Impactum, pressupõem a aceitação plena e sem reservas dos Termos e Condições de Uso destas Bibliotecas Digitais, disponíveis em https://digitalis.uc.pt/pt-pt/termos.

Conforme exposto nos referidos Termos e Condições de Uso, o descarregamento de títulos de acesso restrito requer uma licença válida de autorização devendo o utilizador aceder ao(s) documento(s) a partir de um endereço de IP da instituição detentora da supramencionada licença.

Ao utilizador é apenas permitido o descarregamento para uso pessoal, pelo que o emprego do(s) título(s) descarregado(s) para outro fim, designadamente comercial, carece de autorização do respetivo autor ou editor da obra.

Na medida em que todas as obras da UC Digitalis se encontram protegidas pelo Código do Direito de Autor e Direitos Conexos e demais legislação aplicável, toda a cópia, parcial ou total, deste documento, nos casos em que é legalmente admitida, deverá conter ou fazer-se acompanhar por este aviso. 


\section{$\forall$ \\ TAS DAS I JORNADAS LUSÓFONAS DE CIÊNCIAS E TECNOLOGIAS DE INFORMAÇÃO GEOGRÁFICA}

Editores

José Gomes dos Santos

Cidália Fonte

Rui Ferreira de Figueiredo

Alberto Cardoso

Gil Gonçalves

José Paulo Almeida

Sara Baptista 


\begin{abstract}
ARTIGO 9
ORGANISMOS GENÉTICAMENTE MODIFICADOS:

A NECESSIDAdE DA CORRETA DELIMITAÇÃo E DIVULGAÇÃo

DO ESPAÇO DESTINADO AO PLANTIO COMO MECANiSMO

DE PROTEÇÃO AMBIENTAL
\end{abstract}

NOGUEIRA, Luana P.

Mestranda em Direito pela Universidade de Coimbra, Pç. Porta Férrea, 3004-530 Coimbra, Portugal

Tel: +351 913637143; email: Luana-pn@hotmail.com

\title{
RESUMO
}

O cerne do presente trabalho é a possibilidade ou não de co-existência de culturas naturais ou biológicas, entendam-se estas como organismos não modificados geneticamente por manipulação do homem com culturas de organismos geneticamente modificados, sendo muito debatida a questão da migração genética. Sabe-se que a proximidade entre as espécies e a possibilidade de polinização podem gerar a migração genética entre as culturas e este efeito seria nefasto. Nesse sentido, o presente estudo pretende analisar as possibilidades de uma correta delimitação das áreas de plantio de organismos geneticamente modificados e de organismos não geneticamente modificados, de forma que se possa estabelecer uma distância segura entre elas, a qual permita o cultivo de ambas as espécies sem prejudicar a biodiversidade e conseqüentemente a segurança alimentar. Ato contínuo, pretende enfatizar-se a necessidade de um sistema de monitorização e divulgação para o conhecimento público das áreas em que é realizado o cultivo dos alimentos modificados, mais claramente fazer uso da Diretiva Inspire. 


\title{
PALAVRAS-CHAVE
}

Organismos geneticamente modificados, Miscigenação genética, Biodiversidade, Correta delimitação do espaço, Inspire.

\author{
ORGANISMS GENETICALLY MODIFIED: THE \\ NEED FOR CORRECT DELINEATION AND DISSEMINATION \\ OF SPACE FOR THE PLANTING AND ENVIRONMENTAL \\ PROTECTION MECHANISM
}

\begin{abstract}
The focus of this study is whether or not the co- existence of natural or organic crops , they understand themselves as non-GMOs by manipulation of man with crops genetically modified organisms being hotly debated the issue of genetic migration. It is known that the close proximity between the species and the possibility of genetic pollination can generate migration across cultures and this effect would be detrimental. In this sense, the present study aims to analyze the possibilities of a correct delineation of areas for planting of genetically modified organisms and non-genetically modified organisms, so that we can establish a safe distance between them, which allows the cultivation of both species without harming biodiversity and therefore food security. Immediately thereafter, meant to emphasize the necessity of a system of monitoring and disclosure to the public knowledge of the areas in which the cultivation of modified foods, more clearly make use of the Inspire Directive is performed.
\end{abstract}

\section{KEYWORDS}

Genetically modified organisms, Genetic admixture, Biodiversity, Correct delineation of space, Inspire.

\section{INTRODUÇÃO}

A evolução em termos de produção alimentar tem sido uma constante nos últimos séculos, passamos da era rudimentar, baseada na pequena plantação destinada apenas ao consumo familiar, até a atual explosão da indústria alimentar presente no século XXI. O alimento deixou de ser um cultivo destinado aos pequenos grupos (aldeias) e passou à escala global, sendo permitida a sua produção e envio para todos os cantos do globo.

Juntamente a este fenômeno de globalização da produção e da cir- 
culação de produtos alimentares ocorreram as grandes descobertas da ciência, que propiciaram desde a clonagem animal até os melhoramentos alimentares.

Objeto de grande controvérsia quanto a sua segurança ou não para o meio ambiente e seres humanos, os organismos geneticamente modificados $^{1}$ são um exemplo da evolução em termos de alimentos.

Por ainda se tratarem de certa "novidade", os organismos supracitados deixam dúvidas quanto à sua concreta não lesão ao meio ambiente e à saúde humana. Se seu plantio pode ou não gerar danos ao solo, às demais espécies, aos humanos, aos ecossistemas em geral é uma incerteza que leva muitos a se manifestarem contrariamente à sua liberação, sob a alegação de precaução para com o ambiente, a biodiversidade e a segurança alimentar.

Analisar todas as possibilidades envolvidas no cultivo desses alimentos não se faz possível no presente trabalho, sendo conveniente referir-se apenas que severas são as normas às quais são expostos antes de sua aprovação e liberação no mercado, de forma a se buscar ao máximo a certeza de que não oferecem riscos graves. Evidente, contudo, a impossibilidade da absoluta asserção, uma vez que os danos ambientais geralmente são percebidos ao longo do tempo e com a monitorização dos espaços e espécies.

O cerne deste trabalho e também alvo de grandes questionamentos é a possibilidade ou não de co-existência de culturas naturais ou biológicas, entendam-se estas como organismos não modificados geneticamente por manipulação do homem com culturas de organismos geneticamente modificados, sendo muito debatida a questão da migração genética.

1 Os Organismos Geneticamente Modificados são organismos manipulados geneticamente, de modo a favorecer características desejadas, como a cor, tamanho etc. Os OGMs possuem altera-ção em trecho(s) do genoma realizadas através da tecnologia do RNA/DNA recombinante ou engenharia genética. Disponível online em: http://pt.wikipedia.org/wiki/ Organismos_geneticamente_modificados (acedido em 07 Março, 2014). De acordo com a Diretiva 2001/18/CE, em seu artigo $2^{\circ}, \mathrm{n}^{\circ}$ II - "Organismo geneticamente modificado" (OGM), qualquer organismo, com excepção do ser humano, cujo material genético tenha sido modificado de uma forma que não ocorre naturalmente por meio de cruzamentos e/ ou de recombinação natural. Disponível online em: http://eur- lex.europa.eu/smartapi/cgi/ sga_doc?smartapi!celexapi!prod!CELEXnumdoc\&lg=PT\&numdoc=301L0018\&model $=\mathrm{u}$ chett (acedido em 11 Março, 2014) 
Sabe-se que a proximidade entre as espécies e a possibilidade de polinização podem gerar a migração genética entre as culturas e este efeito seria nefasto, uma vez que a manutenção da integridade genética das culturas naturais é de fundamental relevância.

Nesse sentido, o presente estudo pretende analisar as possibilidades de uma correta delimitação das áreas de plantio de organismos geneticamente modificados e de organismos não geneticamente modificados, de forma que se possa estabelecer uma distância segura entre elas, a qual permita o cultivo de ambas as espécies sem prejudicar a biodiversidade e conseqüentemente a segurança alimentar. ${ }^{2}$ Ademais, admite-se também como meio de manutenção da aludida segurança a utilização de técnicas de bloqueio da polinização.

Ato contínuo, pretende enfatizar-se a necessidade de um sistema de monitorização e divulgação para o conhecimento público das áreas em que é realizado o cultivo dos alimentos modificados, mais claramente fazer uso da Diretiva Inspire. ${ }^{3}$

Para isso, faz-se necessária uma abordagem acerca do princípio da precaução, da prevenção, da informação, do afastamento preventivo e da integração ambiental, como forma de manutenção da segurança alimentar e da biodiversidade no cultivo de organismos geneticamente modificados, bem como uma clara demonstração da importância de um trabalho conjunto do Direito com a Geografia, ou seja, o Geodireito.

\section{ORGANISMOS GENETICAMENTE MODIFICADOS}

Os organismos geneticamente modificados são resultado de um avanço da ciência que, em princípio, permite, através de uma determinada mani-

\footnotetext{
${ }^{2}$ Aqui, no sentido de que o indivíduo não seja obrigada a consumir alimentos geneticamente mo-dificados em virtude da impossibilidade de cultivo dos orgânicos ou biológicos devido a contami-nação das culturas por genes modificados.

3 Diretiva Inspire criada no intuito de estabelecer um nível de proteção elevado e dar cumprimen-to ao princípio da integração ambiental, é um mecanismo que permite o acesso a dados infra-estruturas, sobre instalações poluentes, sobre epidemiologia, sobre valores naturais, dentre outros. Cria uma infra-estrutura de informação geográfica na União Européia. Diretiva 2007/2/CE Do Parlamento Europeu e do Conselho de 14 de março de 2007. Disponível online em: http://eur-lex.europa.eu/LexUriServ/LexUriServ.do?uri= OJ:L:2007:108:0001:0014:PT:PDF (ace-dido em 07 Março, 2014)
} 
pulação, a produção de espécies vegetais com características diferentes de acordo com o objetivo pretendido, como por exemplo, mais resistentes ao frio, a pragas, vírus, doenças, insetos, determinados pesticidas ${ }^{4}$, mais ricas em alguns nutrientes e vitaminas, dentre outros. ${ }^{5}$

Em outros termos, através da manipulação genética os genes de um organismo são transferidos para outro, obtendo-se um novo organismo, ao qual se dá o nome de geneticamente modificado ou transgênico. E são as sementes derivadas dessa engenharia biotecnológica que vão dar origem as novas espécies.

Cumpre referir que, apesar de geralmente utilizados como sinônimos, os organismos geneticamente modificados e os transgênicos comportam certas diferenças, pois enquanto os primeiros são derivados da introdução de genes de outro organismo da mesma espécie, os segundos tiveram sua estrutura original modificada por genes de espécies diferentes. ${ }^{6}$

Contudo, essa diferença não se faz presente nos textos que regulam esses organismos. Para o protocolo de Cartagena ${ }^{7}$, organismo geneticamente modificado (OGM) "é qualquer organismo que tenha uma combinação de material genético inédita, obtida por meio do uso da Biotecnologia moderna".

A Diretiva 2001/18/CE os definiu como "qualquer organismo, com exceção do humano, cujo material genético tenha sofrido modificação de uma forma que não ocorre naturalmente por meio de cruzamentos e/ ou recombinação natural". 8

${ }^{4}$ LEITÃO, Alexandra. Insegurança e produtos transgênicos. In: Economia Pura. Ano 8, $\mathrm{n}^{\circ} 75$ (2006), pág. 125.

5 Os Organismos geneticamente modificados que já são de comércio mais comum na Europa são os derivados de soja, milho e de óleo.

${ }^{6}$ MORGATO, Melissa. Organismos geneticamente modificados: algumas questões jurídicas. In: Estudos de Direito Alimentar. Faculdade de Direito da Universidade de Lisboa. Lisboa, 2013, pág. 146. Disponível online em: http://www.icjp.pt/sites/default/files/publicacoes/ files/ebook_diralimentar_out2013.pdf (ace-dido em 13 Março, 2014).

7 Protocolo de Cartagena sobre Biodiversidade. Artigo $3^{\circ}(\mathrm{g})$ : "Living modified organism" means any living organism that possesses a novel combination of genetic material obtained through the use of modern biotechnology". Disponível online em: http://bch.cbd. int/protocol/text/ (acedido em 16 Março, 2014)

8 Artigo $2^{\circ}, n^{\circ} 2$, da Diretiva 2001/18/CE do Parlamento Europeu e do Conselho, de 12 de Março de 2001, relativa à libertação deliberada no ambiente de organismos geneticamente modificados e que revoga a Diretiva 90/220/CEE do Conselho. Disponí- 
Foi a partir do final da década de 80 e início dos anos 90 que os produtos geneticamente modificados começaram a chegar ao mercado 9 , através de tomates, milho, batata, café, soja, dentre outros. O universo dos OGMs é muito vasto e ainda não definido, podem se tratar desde alimentos destinados para o consumo humano até rações para animais.

Segundo Maria João Estorninho $(2008,22)$ já se pode falar em pelo menos três gerações de organismos geneticamente modificados. A primeira foi a dos produtos agrícolas modificados com a finalidade de melhorar as suas características; a segunda dos alimentos funcionais e a terceira dos produtos alimentares denominados biofábricas, uma vez que estes últimos teriam a função de conter medicamentos. ${ }^{10}$

Presentes nessas gerações de OGM estão às promessas de maior qualidade dos alimentos, aumento da produção, eliminação ou diminuição da desnutrição no mundo (cerca de 2.500 milhões de habitantes do planeta sofrem de desnutrição e 850 milhões morre de fome), enriquecimento com ferro ou vitamina $\mathrm{C}$ e, ainda, a possibilidade de maior produção de alimentos em menor quantidade de terra. ${ }^{11}$

Apesar de se tratar de um momento em que a ciência impera, como se percebe através dessa verdadeira explosão de novos alimentos, o que faz com que subsistam tantas incertezas a respeito destes organismos é o fato de serem muito recentes e ao mesmo tempo inovadores, sendo seus impactos ambientais pouco conhecidos, mas que não permitem o descarte da possibilidade de afetar as gerações futuras. E, exatamente em face da inexistência de antecedentes temporais é que as conclusões relativas aos efeitos do uso e consumo desses organismos são feitas através de análises e testes ${ }^{12}$, não havendo como se falar em experiência

vel online em: http://eur- lex.europa.eu/smartapi/cgi/sga_doc?smartapi!celexapi!prod! CELEXnumdoc\&lg=PT\&numdoc=301L0018\&model=guichett (acedido em 11 Março, 2014)

9 ESTORnINHO, Maria João. Segurança Alimentar e a Proteção do Consumidor de Organismos Ge-neticamente Modificados. Almedina. Coimbra, 2008, pág. 22.

${ }^{10}$ Idem, pág. 26

11 MUÑOZ, Emilio. Biotecnología y sociedad: encuentros y desencuentros. Cambridge University Press. Madrid, 2001. Págs. 125/126.

12 CASSELA, Àssima Farhat Jorge (Dissertação Mestrado). A implementação do Princípio da Precau-ção pela União Européia no comércio internacional de OGMs: uma análise do posicionamento da OMC. Coimbra, 2009, pág. 49. 
adquirida com o tempo.

Nesse sentido, a aplicação dessa tecnologia é regulada em detalhes pela União Europeia, ${ }^{13}$ através de um regime jurídico complexo e inovador $^{14}$ que incide sobre cada uma das fases de investigação laboratorial, libertação experimental, colocação no mercado para cultivo, colocação como produto ara alimentação humana ou como alimento para animais, importação ou transformação em produtos industriais.

Cumpre referir que apesar de toda essa regulação em torno dos organismos geneticamente modificados, ainda permanecem incertos os reflexos ou impactos dessas espécies, em especial à longo prazo. ${ }^{15} \mathrm{O}$ que deixa margem a dúvidas acerca do quanto há de positivo ou negativo nesses elementos.

\section{RISCOS VERSUS BENEFÍCIOS}

Um pouco difícil de mensurá-los com base em um juízo de certeza, tendo em vista que a própria ciência ainda se vê incerta quanto aos reais riscos apresentados pelos organismos modificados e em que proporção os seus possíveis benefícios poderiam ser superiores.

Porém, apontar como todo negativo ou positivo um OGM é um ato muito precoce, pois os próprios argumentos científicos ainda são vagos no sentido da poluição dos genes recombinantes e há falta de estudos abrangentes quanto os riscos tanto para o homem como para o meio ambiente. ${ }^{16}$

Contudo, há de se admitir alguns benefícios já alcançados por esses

13 GONÇALVES, Maria Eduarda. Regulação do risco e risco da regulação o caso dos organismos ge-neticamente modificados. In: Estudos comemorativos dos 10 anos da Faculdade de Direito da Universidade de Lisboa. Vol.1. Almedina. Coimbra, 2008, pág. 446.

14 Diretiva 90/219/CE (modificada pela Diretiva 98/81/CE); Diretiva 2001/18/CE; Regulamento (CE) $n^{\circ} 1829 / 2003$; Regulamento (CE) n ${ }^{\circ} 1830 / 2003$ e Regulamento (CE) $n^{\circ} 1946 / 2003$.

15 GONÇALVES, Maria Eduarda. Regulação do risco e risco da regulação o caso dos organismos ge-neticamente modificados. In: Estudos comemorativos dos 10 anos da Faculdade de Direito da Universidade de Lisboa. Vol.1. Almedina. Coimbra, 2008, pág. 445.

16 MORESCHI e DISIMINE, Lucia e Damiano. Lemgambiente e gli OGM: dalle garanzie per la salute Allá tutela delle biodiversità e della tipicità delle produzioni agroalimentaria. In: Notizie di Politeia. Rivista di Etica e Scelte Pubbliche. Ano XVII, n 62, 2001, pág. 258. 
organismos. Dentre as várias vantagens anunciadas ou prometidas por essas modificações genéticas temos a possibilidade de uma vida mais longa aos alimentos (frutas e vegetais que estragam com facilidade); o aumento da resistência das colheitas e a conseqüente redução do uso de químicos; maior resistência a insetos e a certos vírus (diminuindo a possibilidade de as plantas contraírem as doenças por eles causadas). Também, o aumento do nível de produção e o seu rendimento ${ }^{17}$.

No rol positivo relativo aos OGMs, ainda é possível assinalar o aumento dos nutrientes em alguns alimentos, como exemplo o da proteína no caso de determinadas espécies de soja e vitamina C nos morangos, sendo estes já constatados em alguns alimentos nutricionalmente mais ricos. ${ }^{18} 19$

Contudo, também não resta certeza quanto à inexistência de malefícios à saúde humana ou ao meio ambiente em decorrência do cultivo dessas espécies, o que deixa uma linha tênue para defensores e opositores

17 MUÑOZ, Emilio: "En el sector de la agricultura cabe mencionar que la biotecnología puede contribuir al incremento de la producción de alimentos por varias vias: aumento em El rendimiento, disminución em El coste de los insumos, desarrollo de nuevos productos de alto valor añadido que satisfagan lãs necessidades de consumidores y productores de alimentos". In: Biotecnología y sociedad: encuentros y desencuentros. Cambridge University Press. Madrid, 2001. Pág. 35.

18 Um exemplo é o caso do "golden Rice" o qual a Monsanto introduziu o betacaroteno, um precur-sor da vitamina A, que pode contribuir para atenuar os casos de cegueira por estafilococo na cór-nea, ou o caso do premio mundial da alimentação, concedido à bioquímica mexicana Evangelina Villegas e ao cientista indiano Surinder Vasal, por terem desenvolvido um tipo de milho mais pro-téico sem o alterar geneticamente. BASTOS, João Pereira. A Convenção sobre Diversidade Bioló-gica e os problemas dos organismos geneticamente modificados. In Revista Portuguesa de Insti-tuições Internacionais e Comunitárias, $\mathrm{n}^{\circ} 4$. Ano 2002, pág. 72. Há também a soja, cujo óleo tem características de azeite de oliva; o algodão, cujas fibras são resistentes, coloridas e uniformes; a canola, cujo óleo tem menor teor de ácidos graxos; o tomate Flavr Savr, com amadurecimento retardado; o cravo cujas flores sofrem alteração nas cores; o morango com quantidade extra de vitamina C e a batata que absorve menos óleo durante a fritura, entre outros vegetais. MORGA-TO, Melissa. Organismos geneticamente modificados: algumas questões jurídicas. In: Estudos de Direito Alimentar. Faculdade de Direito da Universidade de Lisboa. Lisboa, 2013, pág. 148. Dispo-nível online em: http://www.icjp.pt/sites/default/files/publicacoes/files/ebook_diralimentar_out2013.pdf (ace-dido em 13 Março, 2014)

19 Há também a soja, cujo óleo tem características de azeite de oliva; o algodão, cujas fibras são resistentes, coloridas e uniformes; a canola, cujo óleo tem menor teor de ácidos graxos; o toma-te Flavr Savr, com amadurecimento retardado; o cravo cujas flores sofrem alteração nas cores; o morango com quantidade extra de vitamina $\mathrm{C}$ e a batata que absorve menos óleo durante a fri-tura, entre outros vegetais. MORGATO, Melissa. Organismos geneticamente modificados: algu-mas questões jurídicas. In: Estudos de Direito Alimentar. Faculdade de Direito da Universidade de Lisboa. Lisboa, 2013, pág. 148. Disponível online em: http://www.icjp.pt/sites/default/files/publicacoes/files/ebook_diralimentar_out2013. pdf (ace-dido em 13 Março, 2014) 
ferrenhos.

Aponta-se, no tocante à saúde humana, que os organismos modificados podem ser alergênicos e originadores de graves problemas gastrointestinais ou nutricionais em virtude da combinação de genes que o consumidor desconhece quando do seu consumo, bem como que a sua interação com o organismo pode deixar o indivíduo mais resistente a antibióticos como, segundo o Greenpeace, é o caso da canola, milho e tomate transgênicos. ${ }^{20}$ Há, também a possibilidade de riscos completamente desconhecidos pelo consumo desses alimentos ${ }^{21}$, os quais ainda não foram constatados devido à ausência do fator tempo (antecedentes temporais suficientes).

No que tange ao meio ambiente, apesar de poucos conhecidos os seus efeitos no solo, lagos ou rios, a principal preocupação acerca desses organismos é a possibilidade da miscigenação, ou seja, a "transferência de genes das plantas geneticamente modificadas para as culturas tradicionais". ${ }^{22}$ Comprometendo, assim, a biodiversidade e afetando organismos não visados, como exemplo o cruzamento acidental de plantas transgênicas com plantas daninhas que pode acarretar o surgimento de superpragas. $^{23}$ Há o risco de redução do espectro de outras plantas ou ainda a interação com insetos que não são pragas, podendo gerar sua mutação ou mesmo morte.

O risco de miscigenação já é de tal modo aceite como provável no tocante ao cultivo desses organismos, que, tratando-se de produtos alimentares sem recurso a OGM, é aceitável como puro aquele que contenha vestígios em até $0,9 \%$ dos genes modificados. ${ }^{24}$

20 GREENPEACE. Resistência antibiótica em organismos geneticamente modificados. Disponível online em: http://www.greenpeace.org.br/transgenicos/pdf/resistencia_antibiotica.pdf (acedi-do em 16 Março, 2014)

21 eSTORninho, Maria João. Segurança Alimentar e a Proteção do Consumidor de Organismos Ge-neticamente Modificados. Almedina. Coimbra, 2008, págs. 76/77.

22 Idem.

${ }^{23}$ MORGATO, Melissa. Organismos geneticamente modificados: algumas questões jurídicas. In: Estudos de Direito Alimentar. Faculdade de Direito da Universidade de Lisboa. Lisboa, 2013, pág. 162. Disponível online em: http://www.icjp.pt/sites/default/files/publicacoes/ files/ebook_diralimentar_out2013.pdf (ace-dido em 13 Março, 2014).

${ }^{24}$ GONÇALVES, Maria Eduarda. Regulação do risco e risco da regulação o caso dos organismos ge-neticamente modificados. In: Estudos comemorativos dos 10 anos da Faculdade de Direito da Universidade de Lisboa. Vol.1. Almedina. 2007, pág. 452. 
Nesse sentido, os organismos modificados acabam por englobar um mundo de dúvidas que se deslocam entre os grandes benefícios prometidos (alguns já demonstrados) e os riscos que envolvem o seu cultivo (alguns também já constatados).

\section{Princípios Ambientais}

Por se tratar de uma balança de dois pesos - desenvolvimento da biotecnologia e proteção ambiental - é que os organismos geneticamente modificados invocam a exaltação de princípios ambientais como medidas de proteção. Travar a ciência ou colocar em risco o meio ambiente são atos inaceitáveis. Ambos devem andar juntos, desenvolvimento científico e a máxima proteção ambiental dentro deste contexto. Por conseguinte, se invocam os princípios da precaução, prevenção, informação, afastamento preventivo e integração ambiental.

\subsection{Princípio da Precaução}

Utilizado como linha de base em termos de proteção ambiental na União Europeia, este exige a tomada de medidas que visem assegurar a inocorrência ou máxima minimização de um possível dano ao ambiente, ainda que completamente incerto. E como a incerteza científica está diretamente relacionada ao meio ambiente, sobretudo quanto à magnitude, riscos e possíveis impactos, é diante desta que o princípio em tela é chamado a agir. ${ }^{25}$

O princípio da precaução é uma via para a realização da justiça de modo espacial e temporal, é um princípio da justiça inter e intrageracional. ${ }^{26}$

A maior parte dos riscos que invocam o princípio da precaução não são de ocorrência imediata, mas sim retardada, ou seja, seus danos manifestam-se no futuro, mais ou menos próximo, mas geralmente bastante posterior ao momento da tomada de decisão e, consequentemente, os

25 Beltrão, Antônio F. G.. Curso de Direito Ambiental. Método. São Paulo, 2009, pág. 37.

26 ARAGÃO, Alexandra. Princípio da precaução: manual de instruções. Revista do Centro de Estudos de Direito do Ordenamento, do Urbanismo e do Ambiente. n ${ }^{\circ}$ 22, v.2, Ano 11 (2008). Pág. 40. 
atingidos pelos efeitos dessa decisão são as gerações futuras, as quais se encontram completamente impotentes perante as ações da geração atual.

Àquelas é necessário garantir que a herança natural e cultural seja transmitida para que possam continuar a dispor e usufruir da biodiversidade e dos recursos naturais. ${ }^{27}$ Diante disso, o princípio em tela é invocado para uma justiça intergeracional. Noutras palavras, evitar que as gerações futuras sejam prejudicadas pelos atos da geração atual.

Numa perspectiva intrageracional, o princípio da precaução busca evitar que as ações possam causar danos a determinadas comunidades humanas, uma vez que o impacto de uma atividade ambiental pode incidir diretamente sobre uma determinada parte do globo, ou seja, sobre a população residente naquele local. Dessa forma, apresenta-se como um gestor da justiça intrageracional, ou seja, busca evitar a desigualdade entre os cidadãos devido a um dano ambiental.

Um dos norteadores do princípio da precaução, como já mencionado, é a preocupação com as gerações futuras e, nesse sentido, cumpre referir que o nível adequado de proteção que se espera em termos de ambiente é a materialização das presumíveis expectativas das gerações futuras, o qual deve ser definido e tutelado pelos poderes políticos. ${ }^{28}$ Ou seja, aquele risco que apresenta grande probabilidade de violar os deveres das gerações atuais para com as gerações futuras deve ser inaceitável.

$\mathrm{E}$, como inaceitáveis, em termos ambientais, tem-se todos os riscos de perdas irreversíveis que possam dar origem a extinção de espécies. ${ }^{29}$

A precaução tem o intuito de antecipar os perigos suscetíveis de comportar conseqüências nocivas ou irreversíveis para o meio ambiente, a saúde ou de um modo geral a segurança humana. ${ }^{30}$ Ou seja, ele

27 CANOTILHO, J. J. Gomes / MOREIRA, Vital, "Constituição da República Portuguesa anotada", Vo-lume I, $4^{a}$ Edição, Coimbra Editora, Coimbra, 2007, págs. 849/850.

28 Idem, pág, 49.

${ }^{29}$ ARAGÃO, Alexandra. Princípio da precaução: manual de instruções. Revista do Centro de Estudos de Direito do Ordenamento, do Urbanismo e do Ambiente. n ${ }^{\circ}$ 22, v.2, Ano 11 (2008). Pág. 49.

30 GONÇALVES, Maria Eduarda: "Este princípio aplica-se aos casos em que, embora um exame cientifico preliminar revele que é legítimo recear efeitos potencialmente perigosos, decorrentes de um fenômeno, de um produto ou de um processo, para o ambiente e para a saúde das pessoas e dos animais ou para a sanidade vegetal, os dados disponíveis são 
tem sido politicamente aceite como estratégia de gestão de riscos. E, ao estar consagrado na legislação da União Europeia, acaba por impor aos Estados-Membros que não aguardem a confirmação de um risco para tomarem medidas que vise impedi-lo. ${ }^{31}$ Nesse sentido também foi a sua configuração no texto da conferência Rio+20, ao estabelecer que este deve ser observado pelos Estados sempre que estiverem diante de ameaça de risco ao meio ambiente e que a ausência de certeza não pode ser utilizada para adiar medidas de prevenção. ${ }^{32}$

Logo, sua aplicabilidade aos casos envolvendo organismos modificados torna-se imperiosa, uma vez que se está diante da incerteza quanto aos possíveis danos, mas da suspeita pela sua existência, principalmente no tocante a uma contaminação da biodiversidade alimentar.

\subsection{Princípio da Prevenção}

A Convenção sobre Diversidade Biológica que se originou a partir da ECO92 dispõe já em seu preâmbulo ser "vital prever, prevenir e combater na origem as causas da sensível redução ou perda da diversidade biológica". 33 Princípio basilar do direito ambiental, o qual infere a constatação de que é mais eficiente prevenir os danos ambientais do que repará-los. ${ }^{34}$

Este impõe razoável previsibilidade dos danos que podem ocorrer em virtude de determinado impacto. "É uma conduta racional frente a um mal que a ciência pode objetivar e mensurar, que se move dentro

insuficientes, pouco conclusi-vos ou incertos, não permitindo a determinação do risco com suficiente segurança. In: Regulação do risco e risco da regulação o caso dos organismos geneticamente modificados". In: Estudos comemorativos dos 10 anos da Faculdade de Direito da Universidade de Lisboa. Vol.1. Almedina. Coimbra, 2008, pág. 454.

31 CASSELA, Àssima Farhat Jorge (Dissertação Mestrado). A implementação do Princípio da Precau-ção pela União Européia no comércio internacional de OGMs: uma análise do posicionamento da OMC. Coimbra, 2009, pág. 52.

32 Rio+20 "O futuro que queremos". Documento final. Disponível online em: https://rio20. un.org/sites/rio20.un.org/files/a-conf.216-1-1_spanish.pdf.pdf (acedido em 16 Março, 2014)

33 Convenção da Diversidade Biológica. Disponível online em: http://www.mma.gov.br/ estruturas/sbf_dpg/_arquivos/cdbport.pdf (acedido em 16 Março, 2014)

34 BELTRÃO, Antônio F. G.. Curso de Direito Ambiental. Método. São Paulo, 2009, pág. 35. 
das certezas das ciências". 35 Exige a existência do perigo concreto e a necessária adoção de medidas para lidar com eventos previsíveis.

Para este princípio o mais importante é prevenir, pois depois que o dano ambiental já ocorreu torna-se quase impossível a reconstituição da situação anterior ou, ainda que viável, os custos para a reconstituição são demasiado onerosos e geralmente muito superiores aqueles necessários à prevenção. 36 Ou seja, a prevenção deve ser anterior à ocorrência do dano, reconhecendo que determinada atividade pode incorrer em certo dano, mecanismos para evitar ou ao menos minimizar a lesão devem ser colocados em prática.

\subsection{Princípio da Informação}

De grande relevância para o Direito Ambiental, baseado na idéia de que sem suficientes informações sobre as condições do meio ambiente e as causas dos danos ambientais não será possível implantar uma política ambiental efetiva, é um princípio que assegura a publicidade crítica em torno das questões ambientais, bem como possibilita o direito e o dever de participação de forma ciente e consciente dos cidadãos 37 .

Teve sua aparição inicial na Declaração de Estocolmo, em seus princípios 19 e 20, a qual reconhece pela primeira vez o significado da informação para a opinião pública e para uma relação responsável entre o homem e o ambiente. 38

35 HAMMERSHMIDT, Denise. O risco na sociedade contemporânea e o princípio da precaução no Direito Amebiental. pág. 15. Disponível online em: http://www.estig.ipbeja. pt/ ac_direito/riscosociedade.pdf (acedido em 16 Março, 2014)

36 ARAGÃO, Alexandra. Direito Comunitário do Ambiente. pág. 16. Disponível online em: https://estudogeral.sib.uc.pt/bitstream/10316/17431/1/cadernos\%20CEDOUA\%20direito \%20comunitario.pdf (acedido em 16 Março,2014)

37 CANOTILho, J. J. Gomes / MOREIRA, Vital, "Constituição da República Portuguesa anotada”, Volume I, 4ª Edição, Coimbra Editora, Coimbra, 2007, pág. 846.

38 Declaração de Estocolmo de 1972. "Princípio 19 - É indispensável um esforço para a educação em questões am-bientais, dirigida tanto às gerações jovens como aos adultos e que preste a devida atenção ao setor da população me-nos privilegiado, para fundamentar as bases de uma opinião pública bem informada, e de uma conduta dos indivíduos, das empresas e das coletividades inspirada no sentido de sua responsabilidade sobre a proteção e melhoramento do meio ambiente em toda sua dimensão humana. É igualmente essencial que os meios de comunicação de massas evitem contribuir para a deterioração do meio ambiente humano e, ao contrário, difundam informação de caráter educativo sobre a 
Também previsto na Diretiva 90/313/CEE, a qual foi revogada pela Diretiva 2003/4, ambas do Parlamento Europeu. Compreende que deve ser garantido o direito de acesso à informação sobre meio ambiente, bem como esta deve ser disponibilizada e divulgada ao público ${ }^{39}$

No tocante aos organismos geneticamente modificados este princípio veio devidamente ressaltado na Convenção de Aarhus, a qual prevê explicitamente em seu artigo $6^{\circ}, \mathrm{n}^{\circ} 11$, o dever dos Estados de permitir a participação do público nas decisões relativas à emissão deliberada para o meio ambiente de organismos geneticamente modificados. ${ }^{40}$

$\mathrm{O}$ artigo $9^{\circ}$ e artigo $24^{\circ}$ da Diretiva 2001/18/CE ${ }^{41}$, prevêem que o público deve ser informado sobre a liberação experimental e a colocação

necessidade de protegê-lo e melhorá-lo, a fim de que o homem possa desenvolver-se em todos os aspectos. Princípio 20 - Devem-se fomentar em todos os países, especialmente nos países em desenvolvimento, a pesquisa e o desenvolvimento científicos referentes aos problemas ambientais, tanto nacionais como multinacionais. Neste caso, o livre intercâmbio de informação científica atualizada e de experiência sobre a transferência deve ser objeto de apoio e de assistência, a fim de facilitar a solução dos problemas ambientais. As tecnologias ambientais devem ser postas à disposição dos países em desenvolvimento de forma a favorecer sua ampla difusão, sem que constituam uma carga econômica para esses países". Disponível online em: http://www.onu.org.br/rio20/img/2012/01/estocolmo1972. pdf (acedido em 27 Março, 2014)

39 DIRECTIVA 2003/4/CE DO PARLAMENTO EUROPEU E DO CONSELHO de 28 de Janeiro de 2003 relativa ao acesso do público às informações sobre ambiente e que revoga a Directiva 90/313/CEE do Conselho. Disponível online em: http://eur-lex.europa.eu/LexUriServ/LexUriServ.do?uri=OJ:L:2003:041:0026:0032:PT:PDF (acedido em 27 Março, 2014)

40 Convenção de Aarhus (Convenção sobre o Acesso à Informação, Participação do Público no Processo de Toma-da de Decisão e Acesso à Justiça em Matéria de Ambiente), adotada na Comissão Econômica para a Europa das Nações Unidas em 1998. Disponível online em: http://www.gddc.pt/siii/docs/rar11-2003.pdf (acedido em 21 Março, 2014)

41 Diretiva 2001/18/CE - Artigo $9^{\circ}$ - Consulta e informação do público

1. Sem prejuízo do disposto nos artigos $7^{\circ}$ e $25^{\circ}$, os Estados-Membros devem consultar o público e, quando adequado, grupos de interesses sobre a proposta de libertação deliberada. Ao fazê-lo, os Estados-Membros devem estabelecer regras pormenorizadas para essas consultas, incluindo um prazo razoável, de forma a facultar ao público ou aos grupos de interesses a oportunidade de manifestar a sua opinião.

2. Sem prejuízo do disposto no artigo $25^{\circ}$ :

- os Estados-Membros devem facultar ao público informações sobre as libertações deliberadas de OGM abrangidas pela parte $\mathrm{B}$ que forem efetuadas no seu território,

- a Comissão deve facultar ao público as informações constantes do sistema de intercâmbio de informações previsto no artigo $11^{\circ}$.

Artigo $24^{\circ}$ - Informação do público

2. Sem prejuízo do disposto no artigo $25^{\circ}$, devem ser facultados ao público os relatórios de avaliação e os pareceres do(s) comité(s) consultado(s) relativamente a todos os OGM que tenham recebido uma autorização por escrito para colocação no mercado ou cuja colocação no mercado como produtos ou num determinado produto tenha sido recusada ao abrigo da presente directiva. Para cada produto devem ser claramente especificados o ou os OGM nele contidos, bem como a ou as utilizações a que se destinam. 
no mercado de OGM.

Percebe-se que para uma eficaz proteção do meio ambiente, devem-se transcender os limites jurídicos e políticos, fazendo com que os particulares, em parceria com o Estado, promovam o controle do desenvolvimento de técnicas, obras, atividades e riscos advindos das tecnologias latentes. ${ }^{42}$

Quanto aos organismos geneticamente modificados e sua liberação no ambiente, é evidente que esse controle está devidamente tutelado, uma vez que resta clara a preocupação em permitir a participação popular.

Ademais, somente através da informação ambiental é que os cidadãos podem ter um comportamento ecologicamente correto e exercer a ecocidadania, colaborando, assim, para um desenvolvimento mais sustentável e a minimização dos riscos ambientais de determinadas atividades ou atos.

\subsection{Princípio do Afastamento Preventivo}

O princípio do afastamento preventivo consiste na estipulação e respeito de distâncias adequadas entre atividades que ofereçam risco a zonas sensíveis. Essa distância pode ser em decorrência do perigo da atividade que vai ser desenvolvida ou da situação da zona sensível e o bem ali protegido.

São consideradas zonas sensíveis e protegidas por este princípio as zonas residenciais; vias de comunicação; edifícios; zonas de utilização públicas e as zonas naturais. Há também as zonas em que a distância deve ser respeitada devido à possibilidade de sinergia negativa entre a atividade naquela área já desenvolvida e uma nova atividade que se pretenda desenvolver, ou seja, neste último caso busca-se evitar o efeito "dominó", 43 o qual consiste em um dano de maior monta devido a conjugação de fatores que envolvem as diferentes atividades realizadas na

42 LEITE e CAETANO, José Rubens Morato e Matheus Almeida. Aproximações à sustentabilidade material no Estado de Direito Ambiental brasileiro. In: Agrotóxicos: A nossa saúde e o meio am-biente em questão aspectos técnicos, jurídicos e éticos. Funjab. Florianópolis, 2012. Págs. 368/369.

43 ARAGÃo, Alexandra. A prevenção de Riscos em Estado de Direito Ambiental na União Européia. Págs. 20/21. Dis-ponível online em: http://www.ces.uc.pt/aigaion/attachments/Prevencao\%20de\%20Riscos\%20em\%20Estados\%20de\%20Direito\%20A mbien-tal. pdf-1a14060ed87cb105d54a17036cac71fa.pdf (acedido em 17 Março, 2014) 
mesma área.

A idéia de afastamento preventivo não consiste exclusivamente em um afastamento geográfico entre a atividade e a área sensível ou entre as atividades perigosas entre si, mas também traduz a idéia de um afastamento técnico, o qual se dá através de medidas de isolamento preventivas da contaminação do ambiente exterior.

\subsection{Princípio da Integração Ambiental}

Previsto no artigo $37^{\circ}$ da Carta de Direitos Fundamentais da União Européia, está relacionado com a idéia de que "proteger eficazmente o ambiente implica tê-lo em consideração no desenvolvimento de todas as atividades humanas que possam, direta ou indiretamente, afetar os componentes ambientais". ${ }^{4}$

Também compreendido no tratado da União Européia ${ }^{45}$, o presente princípio disciplina que "as exigências em matéria de proteção do ambiente devem ser integradas nas definições e aplicações das demais políticas comunitárias”. Isso decorre do entendimento de que todas as atividades da Comunidade refletem de alguma forma no meio ambiente, desde as políticas agrícolas até às de transportes e desenvolvimento ${ }^{46}$.

De acordo com este princípio não há uma atividade que seja completamente inofensiva ao meio ambiente, já que todas, de alguma forma, em maior ou menor grau, negativa ou positivamente, podem gerar alguma reação ambiental. A dimensão ambiental deve, assim, ser entendida como elemento incontornável na ponderação de bens e interesses transportados pelas várias políticas setoriais ${ }^{47}$. Portanto, disciplina que toda atividade

44 ARAGÃo, Alexandra. Carta dos Direitos Fundamentais da União Européia: Comentada. Almedina. Coimbra, 2013, pág. 450

45 Tratado de Funcionamento da União Européia. Disponível online em: http://eur-lex. europa.eu/LexUriServ/LexUriServ.do?uri=OJ:C:2012:326:0047:0200:PT:PDF (acedido em 21 Março, 2014)

46 ARAgÃO, Alexandra. Direito Comunitário do Ambiente. pág. 23. Disponível online em: https://estudogeral.sib.uc.pt/bitstream/10316/17431/1/cadernos\%20CEDOUA\%20direito \%20comunitario.pdf (acedido em 16 Março,2014)

47 CANOtilho, J. J. Gomes / MOREIRA, Vital, "Constituição da República Portuguesa anotada”, Vo-lume I, 4ª Edição, Coimbra Editora, Coimbra, 2007, pág. 851. 
deve ser vista de acordo com os princípios ambientais e em respeito a estes.

Destarte, permite a análise de uma medida adotada quanto à sua conformação ou não para com os princípios de direito do ambiente, de modo a possibilitar a fiscalização dos atos da comunidade, uma vez que possibilita a impugnação de medidas legislativas ou administrativas, mesmo que não relacionadas diretamente com o meio ambiente, quando se verificar a possibilidade de ocorrência de efeitos inaceitáveis neste. ${ }^{48}$ E consiste na integração de todos os Estados-Membros quanto à adoção de medidas de proteção ambiental.

Essa integração demonstra não apenas a preocupação da Comunidade Europeia para com a preservação ambiental, como também permite a estipulação de ações comuns a todos os Estados-Membros no sentido de evitar danos ao meio ambiente.

\section{DA DELIMITAÇÃo do ESPAÇO PARA CULTIVO DE OGM}

Quando se tem diagnosticada a incerteza de um risco de dano e sua importância é que se deve fazer a escolha das medidas a tomar para evitar que este venha a se concretizar.

A gestão do risco é uma fase disciplinada pela União Européia como de grande importância quanto à estipulação das medidas que devem ser tomadas para evitar a ocorrência de danos. Ela envolve a possibilidade de proibição, autorização condicionada e de acompanhamento pós-comercialização, dentre outras. Vinculada ao princípio da precaução, a gestão torna necessário que sejam sopesados o progresso científico, o risco e o perigo. Ou seja, deve ser formulada sempre com a finalidade de evitar a ocorrência do dano.

Também nesse sentido, o Regulamento (CE) n 1946/2003 do Parlamento Europeu, relativo ao Protocolo de Cartagena, prevê que deve haver uma mobilização entre a comunidade para assegurar um nível adequado de proteção no domínio da transferência, da manipulação e da utilização

48 ARAGÃO, Alexandra. Carta dos Direitos Fundamentais da União Européia: Comentada. Almedina. Coimbra, 2013, pág. 452. 
seguras de OGM que possam ter efeitos adversos na conservação e na utilização sustentável da diversidade biológica. 49

Como já mencionado anteriormente, dentre os riscos que envolvem o cultivo de organismos geneticamente modificados há o medo de contaminação entre espécies e é sobre este que vamos nos debruçar.

Apesar de se tratar de uma "novidade" de efeitos pouco conhecidos, sabe-se que os genes de OGM podem espalhar-se, comprometendo assim a diversidade biológica, quando transmitidos por veículos como abelhas e outros insetos, pássaros ou pulgas do mato ${ }^{50}$, e as próprias condições ambientais como ventos, chuvas, e etc., impedindo a coexistência de espécies modificadas e não modificadas.

Esse risco exige o desenvolvimento de estratégias e melhores práticas para assegurar a coexistência de culturas geneticamente modificadas com a agricultura convencional e a agricultura biológica, visando proteger estas últimas de uma possível contaminação ${ }^{51}$.

Ocorre que, apesar de a Comissão Européia ter criado uma recomendação ${ }^{52}$ de orientações e melhores práticas para evitar a contaminação das espécies, ela deixa muito a cargo de cada Estado a estipulação das medidas a serem tomadas, não especificando quais seriam essas práticas ou definindo as medidas a serem adotadas de forma geral por todos os Estados-Membros da União Europeia. Chega a mencionar que não há nenhum instrumento a ser recomendado para a coexistência, mas que compete aos Estados à criação de instrumentos de política, tais como acordos voluntários e legislação.

49 Regulamento (CE) n. ${ }^{\circ} 1946 / 2003$ do Parlamento Europeu e do Conselho, de 15 de Julho de 2003, relativo ao mo-vimento transfronteiriço de organismos geneticamente modificados. Disponível online em: http://eur-lex.europa.eu/LexUriServ/LexUriServ. do?uri=CELEX:32003R1946:PT:HTML (acedido em 11 Março, 2014)

50 BASTOS, João Pereira. A Convenção sobre Diversidade Biológica e os problemas dos organismos modificados. In Revista Portuguesa de Instituições Internacionais e Comunitárias, n4. Ano 2002, pág. 72 .

51 Commission Recommendation of 23 July 2003 on guidelines for the development of national strategies and best practies to ensure the coexistence of genetically modified crops with con-ventional and organic farming (notified under document number C(2003) 2624). Disponível onli-ne em: http://eur-lex.europa.eu/LexUriServ/LexUriServ. do?uri=CELEX:32003H0556:EN:HTML (acedido em 10 Março, 2014)

52 Idem 
Segundo o Relatório da Comissão Europeia ao Conselho e ao Parlamento Europeu sobre a coexistência de culturas geneticamente modificadas com culturas convencionais e biológicas ${ }^{53}$, as discrepâncias entre as políticas adotadas pelos Estados Membros é grande; enquanto alguns já estipularam distâncias consideradas seguras ou se debruçaram sobre técnicas de bloqueio, como zonas-tampão, outros nem sequer possuem medidas destinadas a regularizar o cultivo desses organismos. Contudo, aponta que todos os Estados realizam consultas as partes interessadas para o desenvolvimento de medidas de coexistência.

Dentre as discrepâncias conhecidas em nível de segurança entre os Estados, pode-se citar o caso de Portugal, que utiliza uma distância de $200 \mathrm{~m}^{54}$ entre o cultivo de OGMs e não OGMs, sendo que, países como Espanha, Estados Unidos, Canadá e França já constataram a ocorrência de contaminação entre as espécies num raio de até $1500 \mathrm{~m}^{55}$.

O exemplo acima evidencia não se estar diante de uma política comum de proteção entre os Estados, pois, como se depreende do relatório já mencionado, alguns dos países membros se dedicam a técnicas de segregação espacial mais ou menos rigorosas, outros a mecanismos de bloqueio, enquanto alguns nem sequer definiram um mecanismo para tal finalidade.

Ainda, na busca de mecanismos de coexistência, a União Européia financiou dez anos de estudos sobre OGM, o que deu origem a alguns projetos. No projeto Transcontainer 56 foi elaborado um estudo sobre estratégias de contenção biológica através da (i) transformação do cloroplasto; (ii) repressão floral; ou (iii) fertilidade controlada das sementes

53 Relatório da Comissão ao Conselho e ao Parlamento Europeu sobre a coexistência de culturas geneticamente modificadas com culturas convencionais e biológicas. Ano 2009. Disponível online em: http://eur- lex.europa.eu/LexUriServ/LexUriServ.do?uri=COM:2009:0153:FIN:en:PDF (ace-dido em 26 Março, 2014)

54 Culturas geneticamente modificadas na agricultura portuguesa: competitividade e sustentabili-dade. Disponível online em: http://www.esac.pt/cernas/ogm.htm (acedido em 10 Março, 2014)

55 FERREIRA, Jorge. Culturas geneticamente modificadas uma ameaça a vida!. Disponível online em: http://www.agrosanus.pt/doc/ogm-milho.pdf (acedido em 11 Março, 2014)

56 Comissão Européia. Uma década de pesquisa em OGM financiada pela UE (2001-2010). Págs. 94/98. Disponível online em: http://cib.org.br/wp-content/uploads/2011/ 11/Uma_decada_de_pesquisa_em_OGM.pdf (acedido em Março, 2014) 
GM. Os dois primeiros apresentaram resultados suscetíveis de serem aplicados somente em espécies determinadas. Já o último, apesar de ter sido satisfatório, ainda se apresenta como um estudo inicial.

O projeto SIGMEA 57 debruçou-se sobre a coexistência sustentável de GM e não GM. Para isso realizou a análise sobre as seguintes espécies geneticamente modificadas: (i) milho; (ii) colza oleaginosa; (iii) beterraba açucareira; (iv) trigo; e (v) arroz. A constatação foi que as medidas de segregação são boas técnicas, contudo, não se pode partir de uma distância específica, mas sim, elas devem ser reguladas de acordo com a espécie a ser cultivada, uma vez que, dentre as analisadas, cada uma apresentou diferentes potenciais de miscigenação, devendo-se, também, levar em consideração as características de cada zona de plantio.

Os estudos demonstram que ainda é muito incerto o risco de contaminação das espécies, o grau de sua ocorrência e quais seriam as melhores formas para evitá-lo. Sabe-se da ocorrência de alguns casos, mas não se pode afirmar que essa seja necessariamente uma conseqüência concreta do plantio de organismos modificados. Contudo, como princípio fundamental do direito ambiental, a precaução recomenda que, diante da mera possibilidade de um dano ao meio ambiente, mecanismos de proteção ou precaução para tentar evitar que este se concretize devem ser postos em prática, ou seja, deve evitar-se a proliferação de danos futuros em contextos de incertezas científicas, sobretudo nas decisões a serem tomadas. ${ }^{58}$

Assim, como o princípio da prevenção também disciplina que uma vez conhecida a possibilidade de uma atividade gerar determinado tipo de dano, é mais inteligente prevenir do que compensar. E, no caso dos OGM já houve a constatação desse dano em alguns países. Ademais, retornar ao status quo é infinitamente mais dispendioso e difícil do que evitar a ocorrência da lesão ambiental.

Exatamente em virtude desse risco de miscigenação ou contaminação de espécies é que se aponta a delimitação do espaço de plantio e a esti-

57 Idem, págs. 99/109.

58 LEITE e CAETANO, José Rubens Morato e Matheus Almeida. Aproximações à sustentabilidade material no Estado de Direito Ambiental brasileiro. In: Agrotóxicos: A nossa saúde e o meio am-biente em questão aspectos técnicos, jurídicos e éticos. Funjab. Florianópolis, 2012. Pág. 364. 
pulação de uma distância segura entre o cultivo dos diferentes organismos (geneticamente modificados e não geneticamente modificados) como um meio de precaução de danos ambientais não aceitáveis. Valendo-se das conclusões dos projetos Transcontainer e SIGMEA é que se discute a delimitação do espaço como uma boa medida de proteção ambiental no tocante aos OGM.

Tanto pode ser estipulado o afastamento necessário entre as culturas para que não ocorra a perca da biodiversidade através da contaminação, como pode ser elaborado um mecanismo de bloqueio que realmente vede qualquer possibilidade de polinização.

Obviamente, não compete ao Direito à estipulação de qual seria a distância ou a prática de bloqueio mais adequada para evitar uma possível contaminação de espécies, mas sim aos profissionais de outras áreas em apoio técnico, como a Biologia e a Geografia, capazes de mensurar uma distância máxima percorrida pela polinização ou qual a possibilidade dessa contaminação se dar através do solo.

Tais profissionais possuem o conhecimento necessário para definir a distância segura para cultivo das culturas biológicas e convencional para com os OGMs de acordo com a localização espacial em que se encontram, bem como definir técnicas capazes de bloquear a polinização.

Estar-se a falar da necessidade de utilização do Geodireito, a congregação do Direito e da Geografia, ou seja, ramo que estuda a relação Espaço-Estado por meio do sistema de cartografia da norma, que objetiva espacializar a cidadania, o que é fundamental em termos de direito ambiental. 59

Ao operador do Direito - como representante do Estado, uma vez que a este compete o dever de defender o ambiente e controlar as ações de degradação ambiental, impondo-lhes as correspondentes obrigações políticas, legislativas, administrativas e penais ${ }^{60}$ - caberia apenas a regula-

59 SANCHES, Luiz Antonio Ugeda. "Legislação Geografia e Geodireito". Palestra in: Geotecnologias na Gestão Pú-blica. Rio de Janeiro UERJ, 2013. Disponível online em: http:// www.youtube.com/watch?v=iVSynoYG4ss (acedido em 27 Março, 2014)

60 CANOtilho, J. J. Gomes / MOREIRA, Vital, "Constituição da República Portuguesa anotada", Vo-lume I, $4^{\mathrm{a}}$ Edição, 
mentação dessa medida, ou seja, a normatização da distância dita segura e dos mecanismos, como meios obrigatórios para os produtores desses alimentos, bem como a atribuição de multa (coima) ou penalização pelo seu não cumprimento.

Ao Geógrafo como representante do Espaço caberia a análise dos solos e das características dos organismos geneticamente modificados e a sua melhor distribuição geográfica com o fim de manutenção da biodiversidade existente, tendo em vista que este é um meio de precaução para o possível dano, não certo, mas provável, que estes organismos podem representar ao meio ambiente.

Nesse contexto, invoca-se o princípio da precaução como fundamento para a necessária ação dos Estados no sentido de organização geográfica das espécies modificadas, uma vez que embora não se tenha certeza do dano, ele é possível e, uma vez conhecida ou havendo suspeita da sua ocorrência, os meios para impedir que o risco venha a se concretizar já devem ser colocados em prática.

Como mecanismo de apoio pode-se suscitar, ainda, o princípio do afastamento preventivo. ${ }^{61}$ Apesar de, como já mencionado, tal princípio ser destinado à proteção de áreas sensíveis, uma vez que tem o escopo de proteger estes espaços contra as atividades humanas que possam colocá-los em risco, baseia-se na estipulação de uma distância mínima de "segurança" entre a respectiva área e uma atividade humana geradora de impacto ambiental.

É exatamente nesse sentido a extensão do princípio em questão ao caso dos OGMs, no momento em que é chamado a estipular o necessário afastamento entre plantações de organismos geneticamente modificados e organismos não geneticamente modificados de forma a precaver a possibilidade de mistura entre as espécies. Ou seja, não apenas num quadro de proteção de áreas de risco, mas sim de prevenção a possíveis riscos de miscigenação entre espécies e conseqüente perda da biodiversidade disponível.

61 Coimbra Editora, Coimbra, 2007, págs. 845/846. É um princípio implícito a toda a legislação em termos de Direito Ambiental. 
Cabe ainda invocar o princípio da integração, uma vez que as medidas destinadas a evitar a miscigenação das espécies devem ser determinadas com vista a abranger toda a União Européia. Logo, a distância mínima segura para o cultivo desses organismos deverá ser observada em todos os Estados-Membros, configurando uma política de integração da proteção ambiental no tocante ao cultivo de organismos geneticamente modificados e de proteção ambiental.

Ressalta-se que a ação dos Estados aqui aludida é uma ação comunitária, ou seja, igualitária e conjunta entre todos os Estados-Membros, de forma a buscar a máxima segurança com base em uma política comum.

\section{DIRETIVA INSPIRE: MEIO DE CONTROLE}

Seguidora do princípio da integração ambiental e um bom mecanismo de efetivação do princípio da precaução quando se trata de organismos geneticamente modificados, a Diretiva Inspire ${ }^{62}$ permite o acesso a um sistema de informação sobre a acessibilidade e interoperabilidade dos dados geográficos, bem como das diversidades geográficas existentes nas diferentes regiões da União Européia. Esta visa estabelecer a criação da infra-estrutura europeia de informação geográfica através da harmonização de dados geográficos dos Estados-Membros e sua disponibilização através de geowebservices.

A presente diretiva abrange informações de âmbito geográfico em formato electrónico. Estas são relativas a zonas sobre as quais um EstadoMembro detém ou exerce uma competência e cobrem temas como as fronteiras administrativas, a observação da qualidade do ar, das águas e dos solos, a biodiversidade, a ocupação dos solos, as redes de transportes, a hidrografia, a altitude, a geologia, a distribuição da população ou das espécies, os habitats, os sítios industriais ou ainda as zonas de risco natural. 63

62 Diretiva 2007/2/CE Do Parlamento Europeu e do Conselho de 14 de março de 2007. Disponível online em: http://eur-lex.europa.eu/LexUriServ/LexUriServ.do?uri=OJ:L: 2007:108:0001:0014:PT:PDF (acedido em 07 Março, 2014)

63 Infra-Estrutura de Informação Geográfica (INSPIRE). Disponível online em: http:// europa.eu/legislation_summaries/environment/general_provisions/128195_pt.htm (ace-dido em 27 Março, 2014) 
O Tratado sobre o funcionamento da União Européia, em seu artigo $11^{\circ}$ 64, prevê que aquilo que versar sobre a proteção do meio ambiente deve ser executado nas políticas e ações da União, com o objetivo de promover um desenvolvimento sustentável, ou seja, prevê a integração dos Estados e meios com vistas a evitar a ocorrência de danos ambientais.

Nesse sentido, a Inspire se apresenta com uma infra-estrutura de informação geográfica que permite um mapeamento das regiões e disponibilização desses dados em rede virtual, logo, importa em um acesso mais claro as realidades ambientais relevantes. Esta diretiva tem o objetivo de promover a disponibilização de informação de natureza espacial (abrangendo desde dados espaciais de natureza trans-setorial a dados espaciais específicos do setor ambiental), a qual deverá ser utilizada quando da formulação ou avaliação de políticas ambientais. Também, visa trazer aos cidadãos informações úteis em termos de ambiente, ${ }^{65}$ efetivando, dessa forma, o princípio da informação ambiental.

Se a necessária informação do ambiente que todo o cidadão deve ter direito abarca dados relacionados à infra-estrutura, instalações poluentes, epidemiologia e inclusive organismos geneticamente modificados, dentre outros, não resta duvida que a sinergia entre o Direito e a Geografia 66 deve ser efetivada e a Inspire apresenta-se como um bom mecanismo

${ }^{64}$ Tratado sobre Funcionamento da União Européia. Artigo 11ㅇ: "As exigências em matéria de pro-tecção do ambiente devem ser integradas na definição e execuçãodas políticas e acções da Uni-ão, em especial com o objectivo de promover um desenvolvimentosustentável". Disponível on-line em:http://eur-lex.europa.eu/LexUriServ/LexUriServ.do?uri= OJ:C:2010:083:0047:0200:pt:PDF (acedido em 14 Março, 2014)

65 Diretiva Inspire. Disponível online em: http://snig.igeo.pt/Inspire/directiva_inspire. asp?menu=1 (acedido em 10 Março, 2014)

${ }^{66} \mathrm{E}$ é relativamente a essa necessária sinergia que cumpre referir que, assim como a importância da aproximação en-tre Direito e Biologia para preservar o meio ambiente e o homem como uma de suas componentes, deu origem ao Biodireito e ao Direito Ambiental, os quais são o reflexo da expressão "desenvolvimento sustentável", expressão que, por sua vez, nada mais é do que a necessidade de conhecer a ecologia e normatizar formas de preservá-la, uma vez que o desenvolvimento não pode comprometer as cadeias alimentares e a existência das gerações presentes e futuras.

O Geodireito surge no cenário do desenvolvimento tecnológico, econômico e ambiental, os quais têm como palco comum o espaço, que, por sua vez, tem como base científica a Geografia. E, é no espaço que as relações humanas ocorrem, sendo, então, de grande importância para harmonizar a escala geográfica perante a jurídica, o estudo deste dentro do Direito. SANCHES, Luiz Antonio Ugeda. O que é Geodireito? Disponível online em: http://www.migalhas.com.br/dePeso/16,MI103305,51045-O+que+e+o+Geodireito (acedido em 24 Março, 2014) 
para efetivação desse direito à informação.

Ademais, os grandes privilegiados com esse mecanismo de controle são os poderes públicos, que podem fazer uso desse mecanismo tanto para o efetivo controle das normas impostas ao cultivo de organismos modificados, como para visualizar a viabilidade ou não de liberação do cultivo em determinadas áreas.

No momento em que a lei define a distância mínima entre o cultivo de OGM e não OGM em cada região da comunidade e em virtude do tipo de espécie cultivada e, ato contínuo se procede à demarcação das áreas em que há o plantio de cada espécie modificada e não modificada colocando-as a disposição no Geoportal Inspire, estar-se-á permitindo o conhecimento dessas áreas e, ao mesmo tempo, a monitorização dos cultivos.

A localização dos OGMs e sua devida demarcação de espaço territorial é uma das principais alternativas a tomar em consideração quando se fala na idéia de precaução de um possível dano a biodiversidade que estes podem vir a gerar em termos de mistura entre as espécies. Ou seja, através da escolha de uma localização mais adequada, optando por aquela que menor risco de dano apresente a coexistência com os organismos não geneticamente modificados e, consequentemente na delimitação de uma distância mínima entre o cultivo das duas espécies (OGM e não OGM), estar-se-à a tentar precaver tal situação de risco.

Frisa-se que a própria Diretiva no $\mathrm{n}^{\circ} 5$ do seu anexo III $^{67}$ prevê, quando se refere à saúde humana e segurança, a demarcação dos organismos geneticamente modificados no Geoportal, sendo que, para além desse item, há outros em que se poderiam introduzir dados relativos ao plantio de OGMs e das espécies biológicas como meio de monitorização das áreas e do espaço entre o plantio das diferentes culturas, como exemplo o campo destinado a distribuição das espécies.

Ao ser lançada no portal a localização espacial de cada plantação de organismos modificados e não modificados, melhor se torna a capacida-

67 Diretiva Inspire, categoria de dados geográficos. Anexo III. Disponível online em: http://snig.igeo.pt/Inspire/temas_anexoiii.asp?menu=2 (acedido em 10 Março, 2014) 
de de monitoramento dos referidos cultivos 68 , bem como a percepção de obediência ou não às regras de segurança, tais como uma distância mínima entendida como segura para o cultivo de cada espécie. Ademais, a possibilidade de maior controle e rastreabilidade é fundamental até mesmo para eventuais regimes de responsabilidade. ${ }^{69}$

A simples estipulação de uma distância aceitável como "segura" em termos ambientais e sua normatização não permite ao poderes públicos e aos cidadãos a certeza do seu cumprimento por aqueles que cultivam estes organismos. Já, com a utilização do portal, faz-se possível um maior controle sobre esses cultivos e conseqüentemente mais efetividade dá-se a lei.

$\mathrm{O}$ ato de controle deixa de estar apenas nas mãos dos titulares de poder e passa também a pertencer ao cidadão que, ao acessar o portal e verificar uma distribuição geográfica incorreta das culturas, pode fazer uso dos mecanismos de denúncia, exercendo sua ecocidadania. Quadro que contribui para o desenvolvimento sustentável, tendo em vista que este se pauta não apenas na proteção do meio ambiente, mas também no fato de os próprios cidadãos serem sujeitos ativos dessa proteção.

Ademais, efetiva o constante da Diretiva 2003/4 do Parlamento Europeu, a qual determina que para o fim de promover uma vasta disponibilização e divulgação de informação ambiental junto ao público, deve-se utilizar as tecnologias telemáticas ou eletrônicas, quando disponíveis. ${ }^{70}$ Assim, a Diretiva Inspire se traduz, também, num mecanismo de efetivação do princípio da informação ambiental.

68 A necessidade de monitoramente das regiões de cultivo dos organismos geneticamente modifi-cados é fixada na Diretiva 2001/18/CE: “(44) Em conformidade com o Tratado, os Estados-Membros poderão tomar outras medidas relativas à monitorização e à fiscalização, designada-mente por organismos oficiais, dos produtos colocados no mercado que contenham ou sejam constituídos por OGM". Disponível online em: http://eur- lex.europa.eu/ smartapi/cgi/sga_doc?smartapi!celexapi!prod!CELEXnumdoc\&lg=PT\&numdoc=301L0018 \&model=g uichett (acedido em 11 Março, 2014)

69 ESTORninHO, Maria João. Segurança Alimentar e a Proteção do Consumidor de Organismos Ge-neticamente Modificados. Almedina. Coimbra, 2008. Pág. 88.

70 DIRECTIVA 2003/4/CE DO PARLAMENTO EUROPEU E DO CONSELHO de 28 de Janeiro de 2003 relativa ao acesso do público às informações sobre ambiente e que revoga a Directiva 90/313/CEE do Conselho. Disponível em: http://eur-lex.europa.eu/LexUriServ/ LexUriServ.do?uri=OJ:L:2003:041:0026:0032:PT:PDF Acesso em: 27.03.2014 


\section{ConCLUSÃo}

Sabe-se que a gravidade dos danos que uma atividade pode causar é menor ou maior de acordo com a extensão, a magnitude, a complexidade, a probabilidade, a reversibilidade e a natureza transfronteiriça do impacto. ${ }^{71}$ E os organismos geneticamente modificados, uma vez misturados com as culturas biológicas, tendem a causar graves danos e de grande extensão à biodiversidade disponível, motivo pelo qual se visualiza a necessidade de uma correta demarcação geográfica legal para estas espécies.

Não se pode travar a ciência diante da dúvida, mas da mesma forma o ambiente, a biodiversidade e a segurança alimentar não podem ficar em risco ou à mercê da incerteza.

Exatamente na busca do equilíbrio entre desenvolvimento e sustentabilidade é que, diante da dúvida quanto à situação fatídica de contaminação entre espécies por OGM, o princípio da precaução, como já mencionado, ordena que pairando incerteza sejam colocados em prática todos os mecanismos que possam evitar ou minimizar os danos prováveis daquela atividade.

Por seguinte, a estipulação de áreas para o cultivo de OGM e não OGM é entendida como meio ideal para a efetivação do princípio da precaução e proteção do ambiente e das espécies naturais, no que toca aos organismos geneticamente modificados.

Assim, a conjugação do Direito, para ditar a norma de plantio, e da Geografia, para melhor delimitar, no contexto do espaço, os locais destinados a esse cultivo e uma distância "segura" entre a cultura geneticamente modificada e não geneticamente modificada, visa possibilitar à coexistência de ambas as espécies.

Nesse sentido é que, se o objetivo do direito pode ser compreendido como o de fazer Justiça por meio da aplicação da norma e o da Geografia planejar e estudar o espaço, o encontro destas duas disciplinas se justifica pela busca do espaço justo. ${ }^{72}$

${ }^{71}$ ARAGÃO, Alexandra. Princípio da precaução: manual de instruções. Revista do Centro de Estudos de Direito do Ordenamento, do Urbanismo e do Ambiente. $n^{\circ}$ 22, v.2, Ano 11 (2008). Pág. 28.

72 SANCHES, Luis Antonio Ugeda. Importância e aspectos ambientais do Geodireito. Disponível em: http://www.observatorioeco.com.br/importancia-e-aspectos-ambientais-do- 


\section{BIBLIOGRAFIA}

ARAGÃo, Alexandra. A prevenção de Riscos em Estado de Direito Ambiental na União Européia. Disponível online em: http://www.ces.uc.pt/aigaion/ attachments/Prevencao\%20de\%20Riscos\%20em\%20Estados\%20 de\% 20Direito\%20Ambiental.pdf-1a14060ed87cb105d54a17036cac71fa.pdf (acedido em 17 Março, 2014)

ARAGÃO, Alexandra (2013). Carta dos Direitos Fundamentais da União Européia: Comentada. Almedina. Coimbra, págs. 447/458.

ARAGÃO, Alexandra. Direito Comunitário do Ambiente. Disponível online em: https://estudogeral.sib.uc.pt/bitstream/10316/17431/1/cadernos\% 20CEDOUA\%20direito\%20c omunitario.pdf (acedido em 16 Março, 2014)

ARAGÃO, Alexandra (2008). Princípio da precaução: manual de instruções. Revista do Centro de Estudos de Direito do Ordenamento, do Urbanismo e do Ambiente. $\mathrm{n}^{\circ}$ 22, v.2, Ano 11. Págs. 9/57.

BEltrão, Antônio F. G. (2009). Curso de Direito Ambiental. Método. São Paulo.

BASTOS, João Pereira (2002). A Convenção sobre Diversidade Biológica e os problemas dos organismos geneticamente modificados. In Revista Portuguesa de Instituições Internacionais e Comunitárias, nº 4, págs. 59/77.

CASSElA, Àssima Farhat Jorge (Dissertação Mestrado - 2009). A implementação do Princípio da Precaução pela União Européia no comércio internacional de OGMs: uma análise do posicionamento da OMC. Coimbra.

CANOTILHO, J. J. Gomes \& MOREIRA, Vital (2007). "Constituição da República Portuguesa anotada”, Volume I, $4^{a}$ Edição, Coimbra Editora, Coimbra.

ESTORNINHO, Maria João (2008). Segurança Alimentar e a Proteção do Consumidor de Organismos Geneticamente Modificados. Almedina. Coimbra.

FERREIRA, Jorge. Culturas geneticamente modificadas uma ameaça a vida!. Disponível online em: http://www.agrosanus.pt/doc/ogm-milho.pdf (acedido em 11 Março, 2014)

GONÇALVES, Maria Eduarda (2008). Regulação do risco e risco da regulação o caso dos organismos geneticamente modificados. In: Estudos comemorativos dos 10 anos da Faculdade de Direito da Universidade de Lisboa. Vol.1. Almedina. Coimbra, págs. 440/471.

HAMMERSHMIDT, Denise. O risco na sociedade contemporânea e o princípio da precaução no Direito Amebiental. Disponível online em: http://www. estig.ipbeja.pt/ ac_direito/riscosociedade.pdf (acedido em 16 Março, 2014)

LEITÃO, Alexandra (2006). Insegurança e produtos transgênicos. In: Economia Pura. Ano 8, $\mathrm{n}^{\circ} 75$, págs. 124/127.

geodireito/ Acesso em: 10.03.2014 
LEITE, José Rubens Morato \& CAETANO, Matheus Almeida (2012). Aproximações à sustentabilidade material no Estado de Direito Ambiental brasileiro. In: Agrotóxicos: A nossa saúde e o meio ambiente em questão aspectos técnicos, jurídicos e éticos. Funjab. Florianópolis, págs. 347/379.

MORESCHI, Lucia \& DISIMINE, Damiano (2001). Lemgambiente e gli OGM: dalle garanzie per la salute Allá tutela delle biodiversità e della tipicità delle produzioni agroalimentaria. In: Notizie di Politeia. Rivista di Etica e Scelte Pubbliche. Ano XVII, nº 62, págs. 257/259.

MORGATO, Melissa (2013). Organismos geneticamente modificados: algumas questões jurídicas. In: Estudos de Direito Alimentar. Faculdade de Direito da Universidade de Lisboa. Lisboa, págs. 143/174. Disponível online em: http://www.icjp.pt/sites/default/files/publicacoes/files/ebook_diralimentar_out2013.pdf (acedido em 13 Março, 2014)

MUÑOZ, Emilio (2001). Biotecnología y sociedad: encuentros y desencuentros. Cambridge University Press. Madrid.

SANCHES, Luis Antonio Ugeda. Importância e aspectos ambientais do Geodireito. Disponível online em: http://www.observatorioeco.com.br/importancia-e-aspectos-ambientais-do- geodireito/ (acedido em 10 Março, 2014)

SANCHES, Luiz Antonio Ugeda (2013). "Legislação Geografia e Geodireito". Palestra in: Geotecnologias na Gestão Pública. Rio de Janeiro UERJ. Disponível online em: http://www.youtube.com/watch?v=iVSynoYG4ss (acedido em 27 Março, 2014)

SANCHES, Luiz Antonio Ugeda. O que é Geodireito? Disponível online em: http:// www.migalhas.com.br/dePeso/16,MI103305,51045-O+que+e+o+Geodireito (acedido em 24 Março, 2014)

\section{SITE}

Comissão Européia. Uma década de pesquisa em OGM financiada pela UE (20012010). Disponível online em: http://cib.org.br/wp- content/uploads/2011/11/ Uma_decada_de_pesquisa_em_OGM.pdf (acedido em 26 Março, 2014)

Commission Recommendation of 23 July 2003 on guidelines for the development of national strategies and best practies to ensure the coexistence of genetically modified crops with conventional and organic farming (notified under document number C(2003) 2624). Disponível em: http://eur-lex.europa. eu/LexUriServ/LexUriServ.do?uri=CELEX:32003H0556:EN:HTML Convenção da Diversidade Biológica. Disponível online em: http://www.mma.gov.br/ estruturas/sbf_dpg/_arquivos/cdbport.pdf (acedido em 16 Março, 2014)

Convenção de Aarhus (Convenção sobre o Acesso à Informação, Participação do Público no Processo de Tomada de Decisão e Acesso à Justiça em Matéria de Ambiente). Disponível online em: http://www.gddc.pt/siii/docs/rar11- 
2003.pdf (acedido em 21 Março, 2014)

Culturas geneticamente modificadas na agricultura portuguesa: competitividade e sustentabilidade. Disponível online em: http://www.esac.pt/cernas/ogm. htm (acedido em 10 Março, 2014)

Declaração de Estocolmo de 1972. Disponível online em: http://www.onu.org. br/rio20/img/2012/01/estocolmo1972.pdf (acedido em 27 Março, 2014) Diretiva 2003/4/CE do Parlamento Europeu e do Conselho de 28 de Janeiro de 2003, relativa ao acesso do público às informações sobre ambiente e que revoga a Diretiva 90/313/CEE do Conselho. Disponível online em: http://eur- lex.europa.eu/LexUriServ/LexUriServ.do?uri=OJ:L:2003: 041:0026:0032:PT:PDF (acedido em 27 Março, 2014)

Diretiva 2007/2/CE Do Parlamento Europeu e do Conselho de 14 de março de 2007. Disponível online em: http://eur- lex.europa.eu/LexUriServ/LexUriServ. do?uri=OJ:L:2007:108:0001:0014:PT:PDF (acedido em 07 Março, 2013)

Diretiva 2001/18/CE do Parlamento Europeu e do Conselho, de 12 de Março de 2001, relativa à libertação deliberada no ambiente de organismos geneticamente modificados e que revoga a Diretiva 90/220/CEE do Conselho. Disponível online em: http://eur- lex.europa.eu/smartapi/cgi/sga_doc?smartapi!celexapi!prod! CELEXnumdoc $\& 1 \mathrm{lg}=\mathrm{PT} \&$ numdoc $=3$ 01L0018\&model=guichett (acedido em 11 Março, 2014)

GREENPEACE. Resistência antibiótica em organismos geneticamente modificados. Disponível online em: http://www.greenpeace.org.br/transgenicos/pdf/ resistencia_antibiotica.pdf (acedido em 16 Março, 2014)

INSPIRE EU. Informação sem fronteiras. Disponível online em: http://snig.igeo. pt/Inspire/oquee.asp?menu=1 (acedido em 10 Março, 2014)

Organismos Geneticamente Modificados. Disponível online em: http://pt.wikipedia. org/wiki/Organismos_geneticamente_modificados (acedido em 07 Março, 2014)

Protocolo de Cartagena sobre Biodiversidade. Disponível online em: http://bch. cbd.int/protocol/text/ (acedido em 16 março, 2014)

Relatório da Comissão das Comunidades Européias ao Conselho e ao Parlamento Europeu sobre a coexistência de culturas geneticamente modificadas com culturas convencionais e biológicas. Ano 2009. Disponível online em: http:// eur- lex.europa.eu/LexUriServ/LexUriServ.do?uri=COM:2009:0153:FIN:en:PDF (acedido em 26 Março, 2013)

Regulamento (CE) n. ${ }^{\circ}$ 1946/2003 do Parlamento Europeu e do Conselho, de 15 de Julho de 2003, relativo ao movimento transfronteiriço de organismos geneticamente modificados. Disponível online em: http://eur- lex.europa. eu/LexUriServ/LexUriServ.do?uri=CELEX:32003R1946:PT:HTML (acedido em 11 Março, 2014) 
Rio+20 "O futuro que queremos". Documento final. Disponível online em: https://rio20.un.org/sites/rio20.un.org/files/a-conf.216-1-1_spanish.pdf.pdf (acedido em 16 Março, 2014)

Tratado sobre Funcionamento da União Européia. Disponível online em: http:// eur- lex.europa.eu/LexUriServ/LexUriServ.do?uri=OJ:C:2010:083:0047: 0200:pt:PDF (acedido em 21 Março, 2014) 
Série Documentos

Imprensa da Universidade de Coimbra

Coimbra University Press

2015

- U M

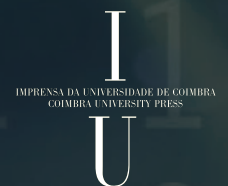

